\title{
直接法を用いた電子回路シミュレーションの 近細粒度並列処理
}

\author{
非会員 前川仁孝 (早稲田大) \\ 非会員田村光雄 (松下電産) \\ 非会員 中山功 (東京電力) \\ 非会員吉成 泰彦 (三菱総研) \\ 正員笠原博德 (早稲田大)
}

\begin{abstract}
Near Fine Grain Parallel Processing of Circuit Simulation Using Direct Method
Yoshitaka Maekawa, Non-member (Waseda University), Mitsuo Tamura, Non-member (Matsushita Electric Industrial Co. L.td.), Isao Nakayama, Non-member (Tokyo Electric Power Company), Yasuhiko Yoshinari, Non-member (Mitsubishi Research Institute), Hironori Kasahara, Member (Waseda University)
\end{abstract}

\begin{abstract}
This paper proposes a parallel processing scheme of electronic circuit simulation using direct method and evaluates performance of the scheme on a multiprocessor system. A special purpose compiler is developed for efficient near fine grain parallel processing of circuit simulation using direct method, which has not been realized in an actual multiprocessor system. The compiler automatically generates circuit simulation program using a special intermediate language from SPICE input data format. The intermediate language has three types of structured control instructions and directives specifying task boundary. The compiler decomposes the program into tasks, analyzes data dependencies among tasks, schedules the tasks to processors and generates optimized parallel machine code. Next the parallel machine code generator generates different machine codes, each of which consists of instructions for task, data transfer and synchronization, for processors by using statically scheduling results.
\end{abstract}

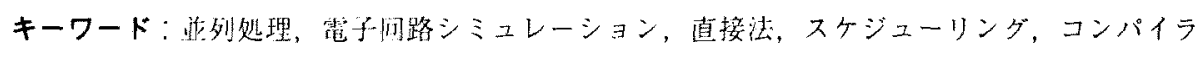

\section{1.まえがき}

本湍文では，直挍解法を用いた電子回路シミュレーショ

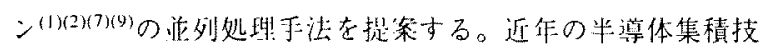
術の進少と其に，VLSIの設胡には，長い丁期と大きな鿓 川が必裂となっている。この亡期の短縮と費用の節減のた めに，CADシステム導人が車裂となっている。その中で

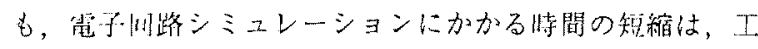

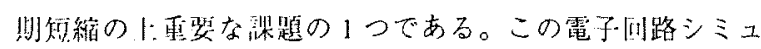
レーションの活速化のためには，スーパーコンピュータな どを川いいた需速化が考えられるが，问路シミュレーション は科学技術計算の中でも最も立列化しにくい計算であり， 例えば，Perfect Club Benchmarkで SPICEをベクトルスー パーコンピュータで夆行した緗果 7\%程度の速度向上しか

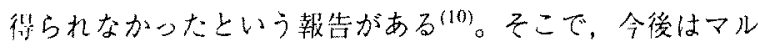

チプロセッサシステムを用いた並列処理が重要になると考 えられる。従来から, 電子回路シミュレータの並列化に関 して多くの研究がなされている(1)(9)(11)。しかし，それらの 研究の多くは，国路分割により亚列性を引き出したり(11), Jacobi 法, Gauss Seidel 洁, SOR 法等の間接法を朋いた乎 法である。間接法は，高い並列性が得られることが知られ ているが，収束性及び適用できる回路が限定されるという 問題点がある。これに対し，本諭文で取り上げる南接法を 用いた乎法は，多くの回路に適用できるが，大きな記憶領 域を必要とし，また，详列処理が非常に困難であることが 知られている。その原因には，淔接法で要求されるランダ ムスパース倸数行列を持つ連立...次方程式の LU 分解等を 用いた求船の並列処理が非常に困難であることがあげられ る。そこで本手法では，この連立方程式求解における LU 分解部のプログラムを，コード生成法(2)(3)(5)を用いて，逐 
次計算において最洞速であることが知られているループフ リーコード(2)(4)に変換し、これを近紌精度タスクで並列处 理する。

本諭文で用いている雱子问路並列シミュレーション用専 用目的コンパイラは，SPICE入力よりシミュレーションプ ログラムを证列化中間語語を用いて自動生成し，さらにこ の中間棓䛇プログラムをタスタへ分割し、データ依你解析 等を行った㣪，並列化マシンコードを生成寸るという方式 をとる。この祭，新たは開発したアプリケーションプログ ラム用並列化中間言語は, 専用目的コンパイラ開発者が, シミュレーションプログラムを自動生成するプログラムの 開発を容易に行えるようにするために構造化制御命命を用 意して沶り，さらに，アプリケーションプログラム固有の 並列性を考虜しつつタスタの精度を最適に設定することを 可能とするためにタスクの粒度の指定ができるように工夫 さ扎ている。また，並列化マシンコ一ド生成部に扔いて む、同一プロセッサ上の夕スク間でのレジス夕を用いた共 有データの授受，タスタ間の同期才ーバーヘッド及び同期 のための記憶領域の最小化などの最適化を行っている。

\section{2. 電子回路シミュレーションの並列処理手法}

本章では，電子回路シミュレーションの並列処理手法の 提案党行方。

く2・1〉電子回路解析手順とタスク生成本節では， 值接法を用いた電子回路シミュレーション手法とプロセッ サへの割り当て単位である夕スクへの分剖法について述べ 名。

電子回路の動特性は一般に，x存接点電压などの $\mathrm{n}$ 個の 姴素からなる解べクトル， $\mathbf{x}_{0}$ を初期值ベクトル， $t$ 老時間 とすると，非線形微分方程式

$\mathbf{f}(\dot{\mathbf{x}}, \mathbf{x}, t)=0 \quad \mathbf{x}(t=0)=\mathbf{x}_{0}$

でモデル化することができる。この非線形漸立微分方程式 を解くために，冬種インプリシット積分法が使用される が，本論文では，Stiff なシステムに強い可变ステップ可変 次数の㮐分法であるBDF(Backward Differential Formulas) 洁(8)を用いて求解を行う。

以下，この求解和順について述べ。

Step 1: BDF 法の予測子 $\mathbf{x}_{i+1}^{p}$ の值を佣いて，次に計算する 時刻での変数の值を予測する。

予測子はBDF法によって，(4)式により定義される $T_{i}$ を係数に持つ連立力程式 ((3)式)を作り，この連立 方程式の解 $\beta$ を (2) 式に代入することにより求める ことができる。この時，(3)式中のT加なる係数行 列は密行列であり，しか心次数kも2 から3程度で寒 用上間題がないので, 各 $\beta$ をを求める計算式はコンパ イル捗にシンボリックに生成することが可能である。 ここでは，この各 $\beta_{i}$ の計算を行う式を1つのタスク として定義する。また，各予測子 $x_{i, t+1}^{p}(i=1, \cdots, n)$ の 値の計算は, 各予测子の部算短に1つのタスクと定義 する。

$$
\begin{aligned}
& x_{t+1}^{p}=\beta_{1} x_{t}+\beta_{2} x_{t-1}+\cdots+\beta_{k+1} x_{t-k} \\
& {\left[\begin{array}{ccccc}
T_{1} & T_{2} & T_{3} & \cdots & T_{k+1} \\
T_{1}^{2} & T_{2}^{2} & T_{3}^{2} & \cdots & T_{k+1}^{2} \\
T_{1}^{3} & T_{2}^{3} & T_{3}^{3} & \cdots & T_{k+1}^{3} \\
\vdots & \vdots & \vdots & & \vdots \\
T_{1}^{k+1} & T_{2}^{k+1} & T_{3}^{k+1} & \cdots & T_{k+1}^{k+1}
\end{array}\right]\left[\begin{array}{c}
\beta_{1} \\
\beta_{2} \\
\beta_{3} \\
\vdots \\
\beta_{k+1}
\end{array}\right]=\left[\begin{array}{c}
1 \\
0 \\
0 \\
\vdots \\
0
\end{array}\right]} \\
& T_{i}=\frac{\text { time }_{i+1}-\text { time }_{t+1-i}}{h}
\end{aligned}
$$

Step 2: BDF 法で求められる微分值を用いて, 非線形微分 方程式を非線形方程式に置き換える。

微分值は，(7) 式により定義される $T_{i}$ を保数に持つ 連立方程式((6) 式)を作り，この湩立方程式の解 $\alpha_{i}$ を(5)式に代人することにより求めることができる。

また，(5)－(7)式中で示した式は，(2)一(4)式と同 様な特徽を持っている。そのため，各 $\alpha_{i}$ の計算式も Step 1 と同様にコンパイル㭙にシンボリックに生成す ることが可能である。ゅえに，タスク生成も Step 1 と

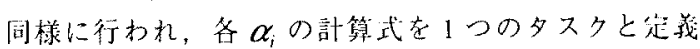
し, 各微分值の計算式每に1つのタスタが走義され 子。

$$
\begin{aligned}
& \dot{x}_{t+1}=-\frac{1}{h}\left(\alpha_{0} x_{i+1}+\alpha_{1} x_{t}+\cdots+\alpha_{k} x_{t-k+1}\right) \\
& {\left[\begin{array}{ccccc}
1 & 1 & 1 & \cdots & 1 \\
0 & T_{1} & T_{2} & \cdots & T_{k} \\
0 & T_{1}^{2} & T_{2}^{2} & \cdots & T_{k}^{2} \\
\vdots & \vdots & \vdots & & \vdots \\
0 & T_{1}^{k} & T_{2}^{k} & \cdots & T_{k}^{k}
\end{array}\right]\left[\begin{array}{c}
\alpha_{0} \\
\alpha_{1} \\
\alpha_{2} \\
\vdots \\
\alpha_{k}
\end{array}\right]=\left[\begin{array}{c}
0 \\
1 \\
0 \\
\vdots \\
0
\end{array}\right]} \\
& T_{i}=\frac{\text { time }_{t+1}-\text { time }_{t+l-i}}{h}
\end{aligned}
$$

Step 3: 非線形方程式をニュートンラフソン近似を朋いて,

線形方程式に置き換える。また,ニュートンラフソン法 の初期值には Step 1 で求めた子湘子の値を用いる。

非線形方程式を解くために，(8)式のニュートンラ フソン法の郭算

$$
\mathbf{x}^{k+1}=\mathbf{x}^{k}-\mathbf{J}^{-1}\left(\mathbf{x}^{k}\right) \mathbf{f}\left(\mathbf{x}^{k}\right)
$$

を行う。この際，(9)式に示されるようなヤコビ行列 の計算が必要になるが，行列の值が定数になる部分に ついては、コンパイル時に計算が行えるために，実行 時に計算を行う必要はない。しかし，变数になる部分 については，奏行時に行列の要点の值を計篟する必妿

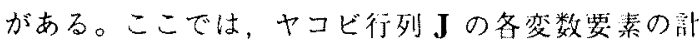
算を1つの夕スタと定義する。

$$
\mathbf{J}=\left[\begin{array}{cccc}
\frac{\partial f_{1}}{\partial x_{1}} & \frac{\partial f_{1}}{\partial x_{2}} & \cdots & \frac{\partial f_{1}}{\partial x_{n}} \\
\frac{\partial f_{2}}{\partial x_{1}} & \frac{\partial f_{2}}{\partial x_{2}} & \cdots & \frac{\partial f_{2}}{\partial x_{n}} \\
\vdots & \vdots & & \vdots \\
\frac{\partial f_{n}}{\partial x_{1}} & \frac{\partial f_{n}}{\partial x_{2}} & \cdots & \frac{\partial f_{n}}{\partial x_{n}}
\end{array}\right]
$$

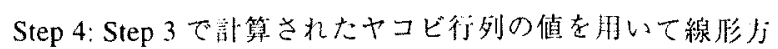


程式を解く。この線班方程式の求解ではクラウト法を用 いたLU 分解，湔進代入，㣪退代入を行う。

Step 3で示さ机な方程式を解くために(8)式の耐辺 にイ加らヤコビ行列 Jをかけたことにより得られる 線形方程式

$$
\mathbf{J}\left(\mathbf{x}^{k}\right) \mathbf{x}^{k+1}=\mathbf{J}\left(\mathbf{x}^{k}\right) \mathbf{x}^{k}-\mathbf{f}\left(\mathbf{x}^{k}\right)
$$

を解く。このスパース楾形力程式の求解のために, 道 接法であるクラウト法老䏘いて LU 分解，前進代入， 後邀代人による敦算孛行う。

方程式を解く際に，行列のリオーダリングを行わず にクラウト法を適用すると，LU分解中にフィルイン が多く慙生增版ししまい計算時間がのびてしまう可 能性があるために，フィルインの発生を抑えるリオ一 ダリング乎法である Markowitz 法(19)を朋いて行う。

また，本前列処理手汒では，このスパース線形方程 式の求解索行うために，SPICEで用いられているコー ド生成法を用いてループフリーコードを生成し並列处 理する。ループフリーコードの生成例を図 1 に示す。 この非答贸素の計算のみの算術代人文を列挙したルー プフリーコードは，通常の Fortran 望語で記述された クラウト㳂プログラムによる求解より，単一プロセッ

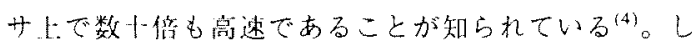
かし，このループフリーコードは，算術代入文のみか

$$
\left[\begin{array}{lllll}
a_{11} & a_{12} & & & \\
& a_{22} & & a_{24} & \\
& & a_{33} & a_{34} & \\
& & & a_{44} & a_{45} \\
& a_{54} & & & a_{55}
\end{array}\right]\left[\begin{array}{c}
x_{1} \\
x_{2} \\
x_{3} \\
x_{4} \\
x_{5}
\end{array}\right]=\left[\begin{array}{c}
b_{1} \\
b_{2} \\
b_{3} \\
b_{4} \\
b_{5}
\end{array}\right]
$$

LU Decomposition
1) $u_{12}=a_{12} / a_{11}$
2) $u_{24}=a_{24} / a_{22}$
3) $u_{34}=a_{34} / a_{3,3}$
4) $l_{54}=-a_{52} \times u_{24}$
5) $u_{45}=a_{45} / a_{44}$
6) $l_{55}=a_{55}-l_{54} \times u_{45}$

Forward Substitution
7) $y_{1}=b_{1} / a_{11}$
8) $y_{2}=b_{2} / a_{22}$
9) $b_{5}=b_{5}-a_{52} / y_{2}$
10) $y_{3}=b_{3} / a_{33}$
11) $y_{4}=b_{4} / a_{44}$
12) $b_{5}=b_{5}-l_{54} \times y_{4}$
13) $x_{5}=b_{5} / l_{55}$

Backward Substitution

14) $x_{4}=y_{4}-u_{45} / x_{5}$

15) $x_{3}=y_{3}-u_{34} / x_{4}$

16) $x_{5}=y_{2}-u_{24} / x_{4}$

17) $x_{1}=y_{1}-u_{12} / x_{2}$

[図1ループフリーコードの生成例

Fig.l. An example of loop free code
らなるスカラ就算であるため、ベタトルプロセッサあ るいはマルチプロセッサ上での並列处理は困難であっ た。本論文では，このループフリーコードを，複数浮 動小数点演算レベルの近緍䊀度タスクに分制しコンパ イラにより最適化を行うことにより効率よい並列処理 を実マルチプロセッサ上で寒現する。

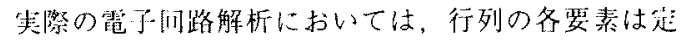
数になる場今と变数になる場命がある。ループフリー コードの式のけで，定数になる部分の計算は，予めコ ンパイル時に計算を行って扔けば寒行時に計算を行う 必要がなくなる。そのうえ，式全体が定数になれば， その式自体の計算を行う必要がなくなる。LU分解で は，計算を左上の裂素から各下の要素へと行うので, ある姴素の計算を行う際は，その要素の同-.列上部及 び同一行左部の曧素が計算に利用さ机る。つまり，定 数をできるたけけの部分に割り付けるように再度り オーダリングを行えば，計算を行うべき要素の計算全 体が定数になる可能性が耍くなり，実行時の計算量を 少なくすることができるため，処理の高速化を图るこ とができる。この計算星削減の様子は，<2・3>節で小 す。

この行列求解部分のタスクの生成は，ループフリー コードの备ステートメント，すなわち，LU行列の各 装素の計算を1つのタスクとして定義する。また，朔 進代入, 後退代入の部分でも, 各要素への代入計算を 1 つの夕スタと定義する。

Step 5: ニュートンラフソン法による計算が収束すれば Step 6へ，収束しなければ Step 3へ。

収束の判断を行うためには，次に示す式を用いる。

$$
\begin{aligned}
& E_{i}=\frac{\text { time }_{i+1}-\text { time }_{1}}{\text { time }_{t+1}-\text { time }_{i-k}}\left|x_{i, t+1}-x_{i, l+1}^{p}\right| \ldots \ldots \ldots \ldots \ldots(11) \\
& E_{\max }=\max \left(E_{1}, \cdots, E_{n}\right)<\mathcal{E} \cdots \cdots \cdots \cdots \cdots \cdots \cdots(12) \\
& \quad \text { たたし } \quad i=1, \cdots, n
\end{aligned}
$$

ここでの収束の判断は，まず变数 $x_{i, j+1}$ の収束計算 を行うために，予測子の值 $x_{i, t+1}^{p}$ と実際の計算結果の 値 $x_{i, t+1}$ より計算さ机る变化尔 $E_{i}$ の計算を1つの夕ス クとして定義する。

最後に，この変化分 $E_{\max }$ 老用いて収束判定在行う ために，いくつかの多スクが定義される。このために 生成される夕スク数は, 力程式の本数 $\mathrm{n} に よ り$ 決定さ れる。

Step 6: シミュレーション終了淕刻まで計算したら終了。そ うでなければ，積分ステップ偪を計算し，次に計算を行 う㭙刻を求めて Step 1 人。

積分ステップは，次に示す式で計算される。

$$
h_{\text {new }}=h_{\text {old }} \times \sqrt[k+1]{\frac{\varepsilon}{E_{\max }}}
$$

積分ステップの計算を行う際, Step 5 で求めた変化 分 $E_{\max }$ の值を用いて計算を行方。ここでは,この部 算を1つのタスタとして定義する。 
$<2 \cdot 2>$ 並列化中間言語生成笔子回路注列シミュ レータの内部では，SPICE人力より図 2 の㥞な谱列化中間 請で䛉逨された回路シミュレーションのプログラムが自

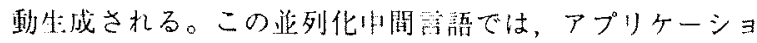
ン固侍の监列性を引き出すために，並列処理においてプロ セッサへの割り当て単位であるタスクの粒度指定が叮能で ある。さらに，本中間苚䛇は，プログラムの記述を容易に するために if-then while-do repeat-until の3つの制御棈造を 用意している。またこれらの制御構造を用いることによ り，プログラムの制御の流れが明確になるために，変数の 低你解析等が突易になる

$$
\begin{aligned}
& :=v 1 \quad c 1 \\
& :=v 2 \quad c 2 \\
& \text { repeat } \\
& +v 1 \quad v 2 \\
& :=v 1 \quad t-1 \\
& +v 2 \quad c 3 \\
& :=v 2 \quad t-1 \\
& \text { until } \\
& <v 2 c 4 \\
& \text { eou } \\
& \text { end }
\end{aligned}
$$

济 2 蓝列化中間言語の生成例

Fig.2. An example of parallel intermediate language

く2・3〉タスクグラフ生成生成されたタスク間に は，ループや条件分岐等の制御構造，及び，フロ一依存や 出力依存や逆低存のようなデー夕依存が存在する。並列処 理においては、これらの制御依存，デー夕依存から生しる 奏行順序制䄪を満たしながら処理を行う必要がある。本回 路シミュレーションに近細粒度夕スクを用いた並列処理を 適用するためには，相対的に大きくなるデー夕転送，同期 オーバーヘッドを㖨小化できるスタティックスケジューリ ングの利用が必須である。しかし，スタティックスケ ジューリングを用いる場合，タスタ閪に条件分岐などの寒 行洔不確定性が保任するとトレーススケジューリング(12)の ような手法が適用できない限り效果的なスケジューリング が行いにくい。そのため本手法では，四3に示す様に， く2・1>節で䢞べた手順をもとに，時間発展ルーブ(外側 ループ）内であるSTEP 1,2の部分とニュートンラフソン ループ（内僋ループ）内である STEP 3,4,5 の部分と時閒発 展ループ内である STEP 6の3つの基本ブロック ${ }^{(16)}$ と呼ば 机る部分に分割してスケジューリングを行う。この3つの 部分内のデータ依存は，图4 に示されるようなタスクグラ フ (14)(15) と呼ばれる無サイタル有问グラフで表される。図 中，タスタはノードに対応しており，ノードの円の内側の 数字は夕スク番号を，ノード横の数字はPEにおける夕ス クの推定処理時間を表している。また，タスタグラフ上の エッジにはデータ伝送を表す仃变の重みが付けがされてお り，エッジの闲端のタスクが，翼なるPEに割り当てられ るならばプロセッサ間のデータ転总時間になり，同じ PE に制り当てられているならばゼロあるいはレジスタやロー

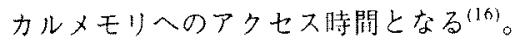

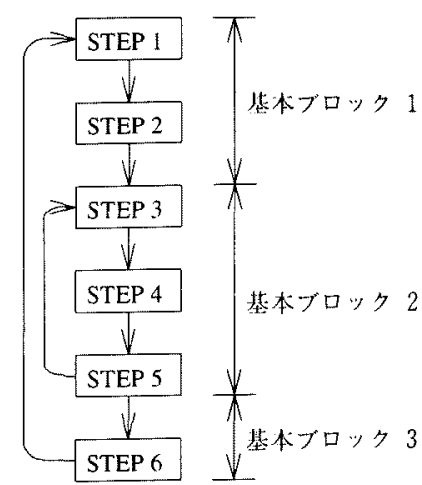

図 3 回路解析におけるスケジューリング箩用 Fig. 3. Scheduling bounds for circuit simulation

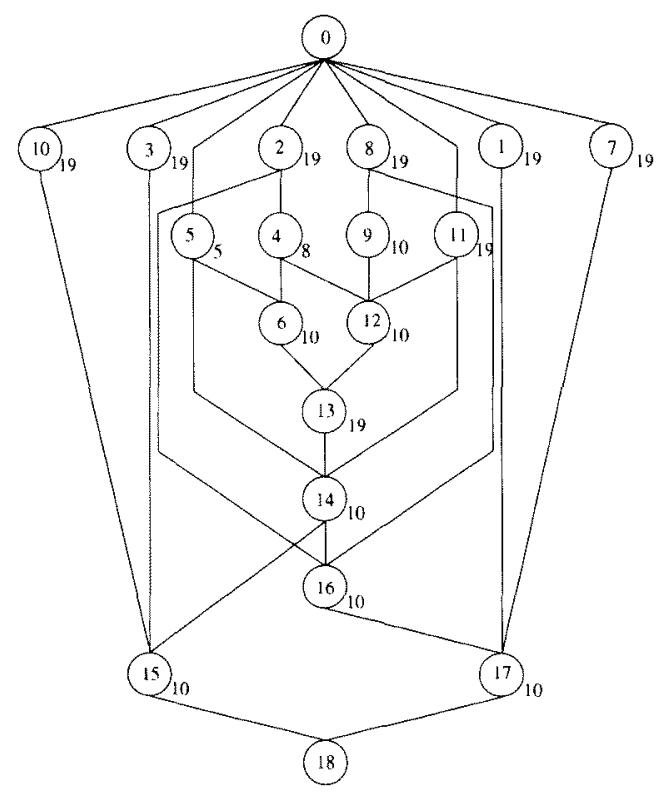

四 4 タスクグラフ

Fig.4. Task graph

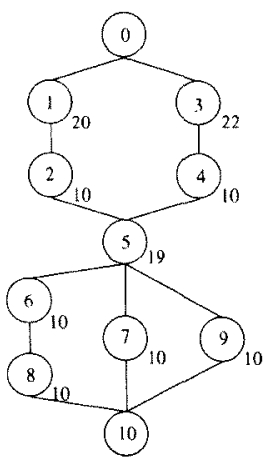

図 5 タスクグラフ

Fig.5. Task graph

T. IEE Japan, Vol. 114-C, No. 5, '94 
ここで，く2・1>節中のStep 4 で速べたリオーダリング手 法を用いることにより計算量が削減される様子を多スクグ ラフを用いて説明を行う。今，因1で示した連立一次方程 式が(14) 式の様な要素配列 ( $C$ : 定数 $V$ : 变数) 持ってい るとする。

$$
\left[\begin{array}{llllll}
C & C & & & \\
& V & & C & \\
& & C & C & \\
& & & V & C \\
& C & & & C
\end{array}\right] \mathbf{x}=\left[\begin{array}{l}
C \\
V \\
C \\
V \\
C
\end{array}\right]
$$

ここで, 〈2・1 節のStep 4 で述べた対角りオーダリングを 行うと (15) 式の様になる。

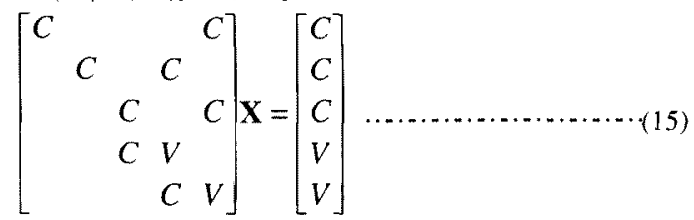

この計算のタスクグラフを図 5 に示す。定数の配置を考慮 した対解リオーダリングを行っていない場合のタスクグラ フ（図 4) と行った場合である(15)式から得られる夕スタ グラフを比較してみると最小並列処理時間である CP 長が 88 クックから71クロックに減り，また全体の計算量む 249 クックから121クロックに減り, 計算量が削減でき ているのが確憵できる。

〈2・4〉 スタティック・スケジューリング・アルゴリズ ムく2・1>節で生成されたタスタのプロセッサへの割り 当てと寒行圙序を決定するスケジューリング問題は，強 NP困難な問題であることが知られているる(13)。この問題を 解くために，様々なヒューリスティックなアルゴリズムや 奏刖的な最適化アルゴリズムが提案されている(14)(15)(16)。 本手法では，スケジューリングに要する時間とスケジュー ル絬果の質を考虑にいれてデータ転送時間を考慮した ヒューリスティックスケジューリングアルゴリズムである CP/DT/MISF 法(17)を用いる。CP/DT/MISF法に扔忛る夕ス ク割り当ての手法は，

1)レディタスクの中から，出门ノードまでの最も長いパ ス長であるレベルが最も高い物を選ぶ (CP)

2) 同じレベルのタスクがある時は，各レデイタスクをア イドルプロセッサに割り当てた祭にデータ転送時間が 最小になるような割り当てを選ぶ (DT)

3)そのような割り当てが複数あれば，直接後続タスク数 が最も多いタスクを選ぶ (MISF)

のような優先順位で割り当てる。また，CP/DT/MISF 法の 峙間複雉さは，タスク数を $n$ プロセッサ台数を $m$ とすると $O\left(n^{3} m\right)$ であり，夕スク数が数千程度のタスクグラフのス ケジューリングに要する胿閒は，通常のワータステーショ ン上で，数秒から擞秒しか要しない。

〈2・5> 最適化並列マシンコード生成実際のマルチ プロセッサシステム上で，效率良い並列処理を行うため に，最適化された並列マシンコードを生成する。このマシ
ンコード生成は，使用するマルチプロセッサシステムの アーキテクチャに依存するので, 本手法のインプリメント を尖際に行ったマルチプロセッサシステム OSCAR ${ }^{(6)}$ 例 に説明する。このOSCARのアーキテクチャについては次 章で簡单に説明する。

本並列処理手法の特徴の1つは，スタティックスケ ジューリング結果を用いて各PEにタスクを割り当てるた めに，各PEに対して巽なるマシンコードを生成するとい うことである。マシンコードの生成例を图 6 に示す。図 6 は，図中に示されているタスクグラフに拀いて，タスク1 とタスク 4 がPE1に割り当てられ，タスタ 3 とタスク 2 が PE2に割り当てられた際に生成されたマシンコードの例で ある。各PEは，自分の持つプログラムメモり上にロード されたマシンコードを，他のPEとデー夕転送や间期を取 りながら実行を行う。

マシンコードの最適化を行う際には， $22 \cdot 4>$ 節で説明を 行った CP/DT/MISF 法の結果より，各PE上で奏行すべき タスクの集合と実行順序，他のPEに割り当てられている 先行タスクからデータが送られてくるまでの推定待ち时 間，タスタ間で同期をとる場所などの情報が利用できる。 これらのスケジューリング情報を利用することによって元 長な同期コードを削除することができる(17)。

\begin{tabular}{|c|c|c|c|}
\hline $\begin{array}{r}\text { PI } \\
* * * \text { Tas } \\
- \text { Task }\end{array}$ & $1^{* * * * *}$ & $\begin{array}{r}\text { PE2 } \\
; * * * * \text { Task } \\
;- \text { Task B }\end{array}$ & $\begin{array}{l}3 * * * * \\
\text { ody }\end{array}$ \\
\hline WVIL & R5, 15 & MVIL & $R 4.1$ \\
\hline LDR & $R 13,[R 5,0]$ & LDR & R14, [R4, 0] \\
\hline MVIL & $\mathrm{R} 4,12$ & MVIL & $\mathrm{R} 5,36$ \\
\hline STR & {$[R 4,0], R 13$} & LDR & $R 15,[R 5,0]$ \\
\hline MVIL & 25,5 & FMLT & $R 13, R 14, R 15$ \\
\hline LDR & $R 13,[R 5,0]$ & MVIL & $\mathrm{R} 4.34$ \\
\hline MVIL & $\mathrm{R} 4,18$ & STR & {$[\mathrm{R} 4,0], \mathrm{R} 13$} \\
\hline STR & {$[R 4,0], R 13$} & : data tra & nsfer : task 4 \\
\hline *** Tas & $4^{* * * *}$ & MVIH & $\mathrm{R} 2,210 \mathrm{H}$ \\
\hline flag cl & ck : Task 3 & MVIL & $\mathrm{R} 2,1789$ \\
\hline MVIL & R3, 1 & STR & {$[R 2,0], R 13$} \\
\hline WIL & $\mathrm{R} 1,1$ & : flag set & \\
\hline & & MVIL & $\mathrm{R} 1, \mathrm{I}$ \\
\hline LR & $\mathrm{R} 2,[\mathrm{R} 3,0]$ & WIH & $\mathrm{R} 2,210 \mathrm{H}$ \\
\hline CMP & $\mathrm{R} 2, \mathrm{Rl}$ & MIL & $\mathrm{R} 2,1$ \\
\hline JLT & $\mathrm{fcl}$ & STR & {$[R 2,0], R 1$} \\
\hline Task & Sody -.. & ;*** Task & $2^{* * * * *}$ \\
\hline MVIL & R3, 1789 & ;-- Task B & ody -- \\
\hline LDR & R14, $[R 3,0]$ & MVIL & $\mathrm{R} 4.5$ \\
\hline WIL & $R 4,34$ & LDR & $\mathrm{R} 14,[R 4,0]$ \\
\hline STR & {$[\mathrm{R} 4,0], \mathrm{R} 14$} & MVIL & $\mathrm{R} 5,2$ \\
\hline MVIL & $\mathrm{R} 4,38$ & LDR & $R 15,[R 5,0]$ \\
\hline LDR & $R 15,[R 4,0]$ & FADD & R13, R14, R15 \\
\hline FMET & R13, R14, R15 & MIL & $R 4,1$ \\
\hline WIL & $\mathrm{R} 4,39$ & STR & {$[R 4,0], R 13$} \\
\hline STR & {$[\mathrm{R} 4,0], \mathrm{RI}$} & & \\
\hline
\end{tabular}

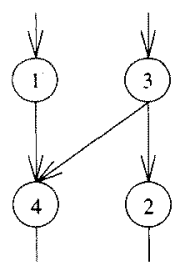

図 6 マシンコード生成例

Fig.6. An example of generated code 
例之ば，集中其有メモりを明いて同期をとる图7の様な

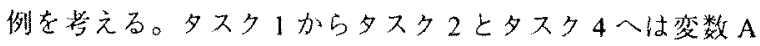
のデータ転送，タスタ 2 からタスク3とタスク 4 ヘは变数

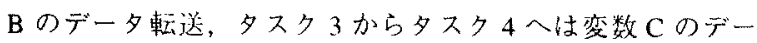
夕転送を行なうとする。この例では，多スク1加らスク

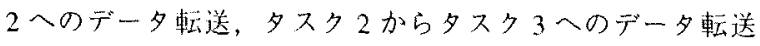
が保任するために，タスク1と夕スク 2 は，タスクるより 前に奉行されていることが保証されているので，タスタ4 は夕スク3の寒行終了を確認するだけでよく，タスク1と タスク 2 の赛行終了を確認をする必要はない。図 7 はこの ようなスケジューリング結果を使用した同期コード除去の 例を示しており，打消し線で表される FS,FCが除去可能 であることを表している。

また，回路シミュレーションを近細粒度タスクレベルで 並列処理をすると，数千から数万以上のタスタが生成され るため，従来のマルチプロセッ专上での細粒度亚列処理の ように，各デー夕每あるいは夕スク每にデー夕転送のアド レスや同期フラダを割り当てる(17)と非常に大きな記憶領域 が消費される。同期に用いる記憶領域を最小化するため に，本手法では，図 8 の椂に各PE上に分散された共有メ モり (DPM)にPE台数分のみのフラグ領域を用意し、デー 夕を受信プロセッサ上の DPM に書き迄んだ後, 送信プロ セッサが何番目のタス夕まで寒行したかを示す值を，受信 プロセッサ上のフラダ領域に書き込む。これにより，プロ セッサ間のデー夕问期制御は，タスク数によらずプロセッ サ台数を $m$ とするとプロセッサ 1 台当たり $O(m)$ の領域 複雑度で寒現できる。

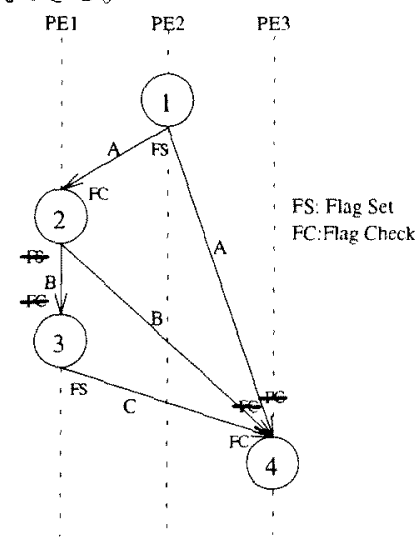

图 7 フラグ削除の例

Fig. 7. An example of flag elmination

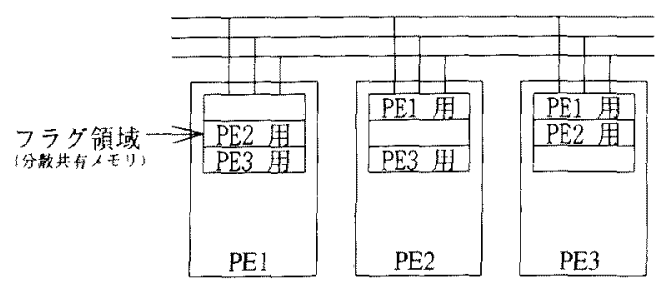

図８フラグチェックの方法

Fig.8. A method of flag check
例えば，PE2がPE1へデータとフラグを転送する際， PE2 からPE1へデー夕証送を行つた後，PE1の DPM 上に あるPE2 用フラグ領域にPE2が何翻目のタスクまで其行終 了したかという倠を其き这む。PE1は，PE1 上にあるPE2 月フラグ領域を調へ，间期を取るべきタスクが奏行終了し たかどうかを調べる。具体的には，PE2が5番田のタスク まで霓行終了した後，PE2からPE1へのデー夕転送が終 了し，PE1はそのデータを利用して寒行叮能になる場命に は，PE1はPE2用フラグ領域に5が菁き込まれるまで待つ か、既に 5 以上の値が書き这まれていればデー夕転送が終 了したことになり，転送したデータが使用可能になる。

また、デー夕転送においても间様にDPMメモり利朋の 最適化を図ることが可能である。OSCARのデー夕転总 モード及びメモりアドレスマップの許細は次章で説明する が，OSCAR上でDPMを用いた2つのデー夕転送モード のうち、ブロードキャストデー夕転送モードを使用する埸 合にはデータのブロードキャスト転送のために全PEの DPMの同一アドレスを確保しておかなくてならない。2 つのデータ転送モードのうちどちらを使用するかを決䇥す る前にデー夕転送アドレスを法定してしまうと，企デー夕 がブロードキャストにより転送されると仮定してアドレス を割り当てなくてはならず，メモりの使用効摔が悪くな る。このためデー夕転送アドレスの割り当てを、デー夕転 送モード決定後に行なうことにより，1対1デー夕転送 モード利用時のデータ転送用メモり領域の舴利用等の DPM 利用最適化を行っている。

\section{OSCARのアーキテクチャ}

本手法の寒現のために使用したマルチプロセッサシステ ムOSCARのアーキテタチャを网 9 に示し, OSCARのメ モリマッブを図10に示す。OSCARとは，单timally Scheduled Advanced Multiprocessor の略で，集中型其有メ モリ(CM) と各プロセッサ上に分散された分散斯有メモリ (DPM)を持った其有メモリ型マルチプロセッサシステムで ある。OSCARは，3本のバスに，鼠大16台のプロセッサ エレメント (PE)，1台のコントロール＆I/O プロセッサ (CIOP)，3モジュールの共有メモりが接続されている。

OSCAR の各PEは, 5MFLOPS の能力を持つ32 ビットの RISC プロセッサ，ローカルデー夕メモリ，ローカルプロ グラムメモリ，分散期有メモリとして使われるデュアル ポートメモリ，スタックメモリ、データのプレロードやボ ストストアに使瑚するDMA コントローラからなってい る。このプロセッサは, 浮動小数点の加算, 減算, 乘算を 念めた全命令を 1 クロック (200ns)で寒行し，他の浮動小 数点演算も固定クロック数で終了する。また，3本のバス

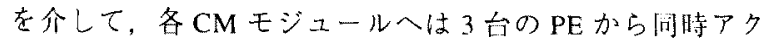
セスが叮能となっている。更に3本のバスは各々高速バリ ア同期機構を持っている。

OSCAR はプロセッサ關データ転送モードとしてDPMを 朋いた1PE 対 1PE 直接データ伝送と1PEから全PEへのブ 


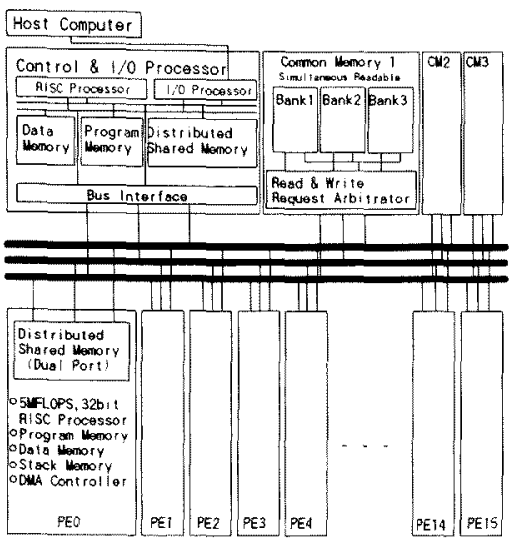

渓 9 OSCARのアーキテクチャ Fig.9. OSCAR's architecture

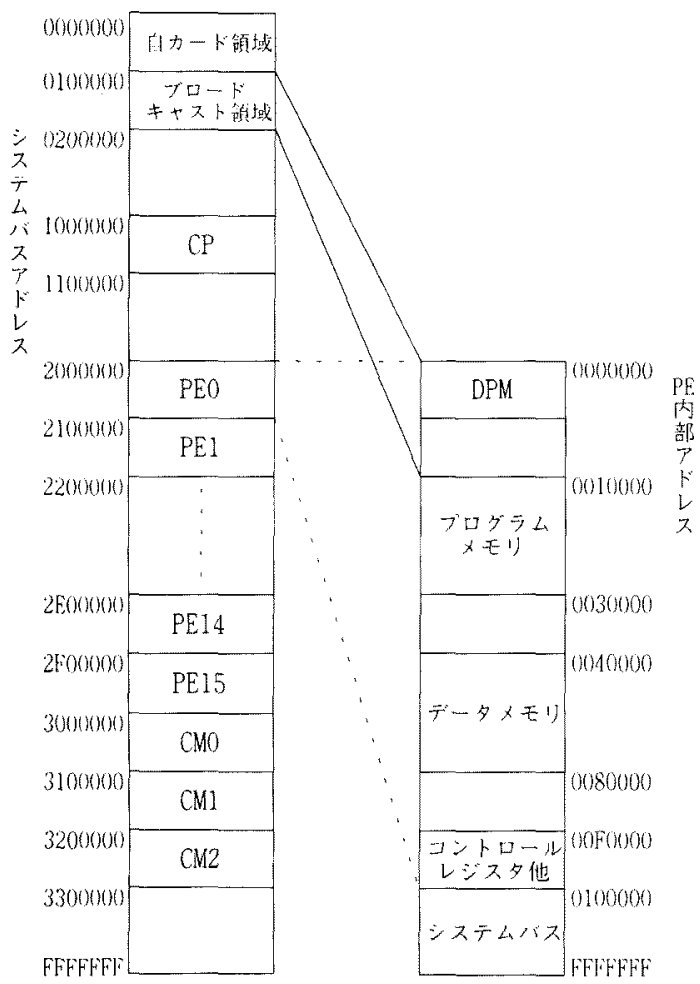

闵 10 OSCARのメモリマップ

Fig.10. OSCAR's memory map

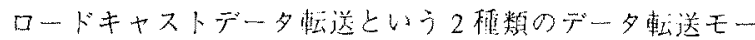

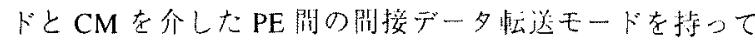

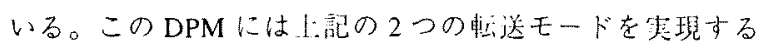
ために、甽10にボすようにPE们部ローカルアドレスに加 えシステムバスアドレスLに1PE对1PE直接デー夕転送 とブロードキャストデータ枟送に用いるためのアドレスが 3重に制り振られている。すなわ方，1対1直接デー夕転 送では，枟送するデータをシステムバスアドレスを用いて

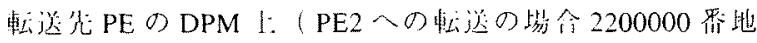

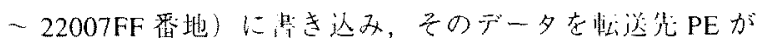
PE 则部ローカルアドレス（00000番地－007FF番地） 䏫て烷みに行くことによりデー夕索慙送することができ

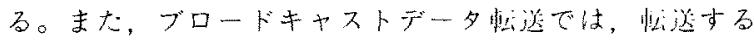
データをブロードキャスト领域(システムバスアドレスは の0100000 番地一01007FF 番地)を指公市ることにより全 PEのDPM 上に㠿き运み，そのデー夕を各PEが流むこと によりデー夕を転选することができる。このブロードキャ ストデー夕転送は，CM老使った複数问のデー夕枟送を行

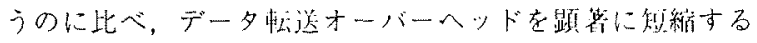
ことができる。従って，デー夕転渓のオーバーヘッドを減 らすためには，スタティックスケジューリングを川いて3 種類のデー夕転送モードを使い分けるこ上が斯紧である。 さらに，同期フラダの授受をDPM 索湖て行うと，间期 のオーバーヘッドも大幅に減少させるこ上ができる。これ

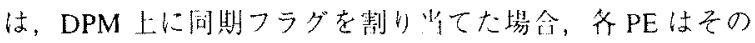
PE内の DPM トにある同期フラグをヂェックすることがで きるので良来の其们メモリマルチプロセッサのように间期 のためのビジーウェイトによる外制バスアクセスの必罗が なくなる。こ扎により间期オーバーヘッドを㩆小化できる と其に，ビジーウェイトに伴うプロセッサ開バスバンド幅 の低下という問㩆を避けることがで尚。

\section{4. 性能評価}

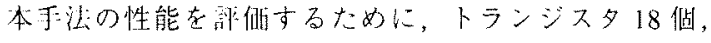

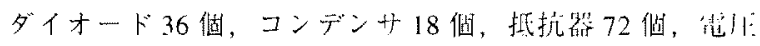

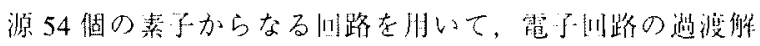
析に桉した時問を测定した。网11は，PE南数に刘して OSCAR にで测资した尖行時間をプロットしたものであ

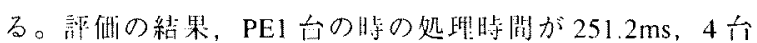

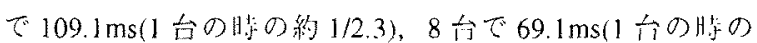
約 1/3.6)と短維されることを碓涩した。网12 は，トラン ジス夕36個，多オート 72 個，コンデン+36個，抵扰 器 144 做, 電压源 108 個の素」からなる回路を川小て, PE 台数に対してOSCAR 上で測盗した筷行㭙間をプロットし

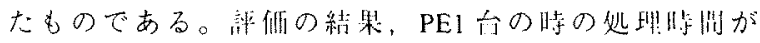
$522.9 \mathrm{~ms}, 4$ 台で 207.9ms (1台の洔の約1/2.5)，8台で $126.5 \mathrm{~ms}(1$ 台の時の約 $1 / 4.1)$ と嵲緶されることを破浲し た。图 13 は，トランジスタ 45 個，ダイオード 90 個，コ

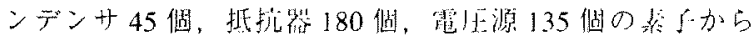
なる国路を肺いて，PE古数に対してOSCAR トで测分した 㭙䦌をプロットしたものである。解优の絬果，PE3台の䏡 の处理时閐が $319.8 \mathrm{~ms}, 4$ 台で $254.6 \mathrm{~ms}, 8$ 台で $158.3 \mathrm{~ms}$ と 知維されることが碓悡された。ただし，PE分数が1台及 び2おの䏽は，プログラムコードの人志さが，OSCARの 备PE 上にあるプログラムメモりの寅量をオーバーしメモ リ1:にロードすることができなかったために測分ができな かった。しかし，全ての場命に执いてPE台数の增引と其 に具行明間が減少することが碓照された。 


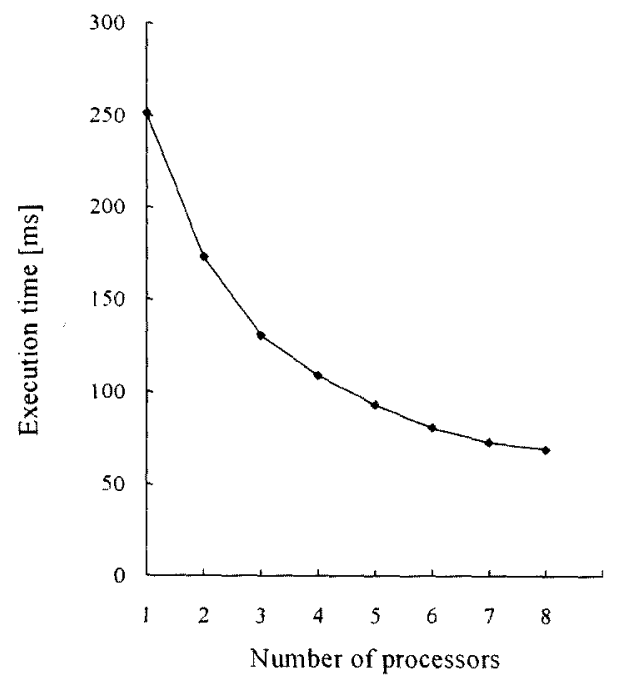

四 11 游列処埋時間

Fig.11. Parallel processing time

以上のように，捝来マルチプロセッサ!での首列㝴理に

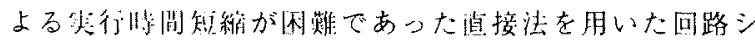
ミュレーションが，提案和厸により其マルチプロセッサ上 で行えることが確かめられた。

\section{5.むすび}

本渝文では，滇接法を䏘いた霓子回路シミュレーション の修列処理丁法を提案し，その有效性の竍価を実マルチプ ロセッサシステムOSCARトで行った。誂価の結果，本並

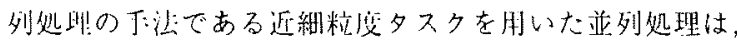
徒米からネックとなっていたスパース行列求解部も令め,

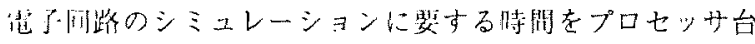

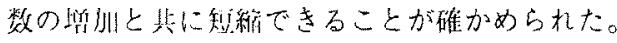

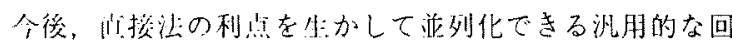

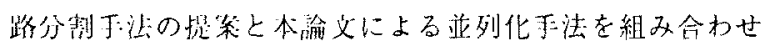

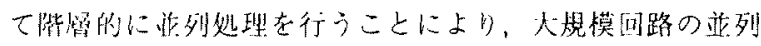
処理を仃能とするテ佂である。

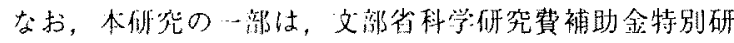

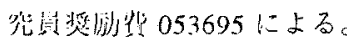

(平成 5 年 4 月9 日受付)

\section{文献}

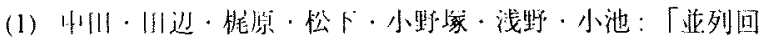
路シミュレーションマシンCenju」, 悄報処理学会誌, 31, No.5. pp.593-601 (1990)

(2) P.Antognetti \& G.Massobrio : "Semiconductor Device Modeling with SPICE", McGraw-Hill Book Company (1988)

(3) I.S.Duff, A.M.Erisman \& J.K.Reid: "Direct Method for Sparse Matrices", Oxford Unjv. press (1986)

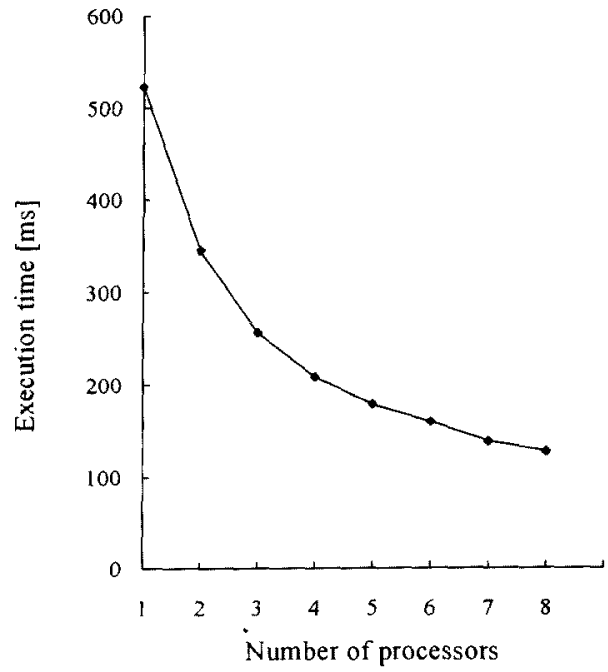

图 12 並列処理時間

Fig. 12. Parallel processing time

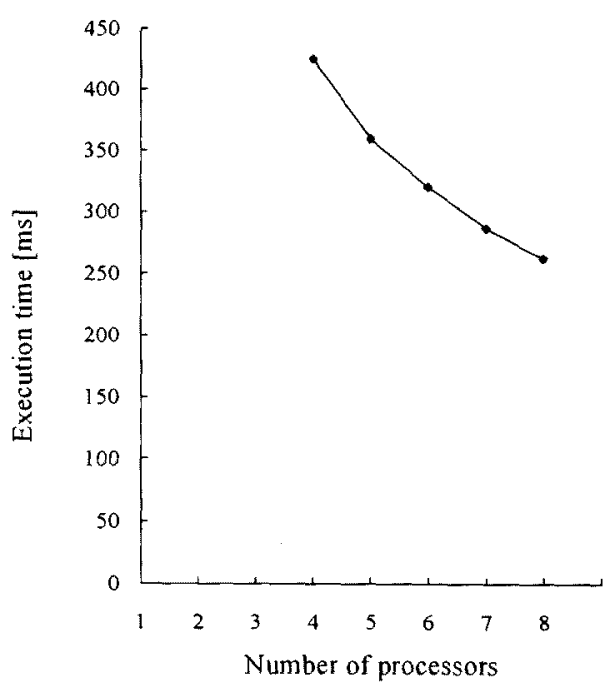

图 13 並列処理時間

Fig. 13. Parallel processing time

(4) Y.Fukui, H.Yoshida \& S.Higono: "Supercomputing of Circuit Simulation", Conf. on Supercomputing'89, pp81-85 (1989)

(5) F.G.Gustavson, W.Liniger \& R.Willoughby : "Symbolic Generation of an Optimal Crout Algorithm for Sparse Systems of Linear Equations", J.ACM, 17, No.1, pp.87-109 (1970)

(6) 笠原・成田・橋本：「OSCARのアーキテクヂや，整了 通信学:会論文誌D, J71-D, No.8, pp.1440-1445 (1988)

(7) C.W.Ho, A.E.Ruehli \& P.A.Brennan : "The Modified Nodal Approach to Network Analysis", IEEE Trans: Circuits and Syst, CAS-22, No.6 (1975)

(8) B.K.Brayton, F.G.Gustavson \& G.D.Hachtel : "A New Efficient Algorithm for Solving Differential Algebraic Systems Using 
Implicit Backward Differential Formulas", Proc, IEEE, 60, No.1, pp98-108 (1978)

(9) P.Sadayappan \& V.Visvanathan : "Circuit Simulation on Shared Memory Multiprocessors", IEEE Trans. Comput., 37, No.12, pp.1634-1642 (1988)

(10) Lynn Pointer: "PERFECT REPORT:1", CSRD Rpt. No.896 (1989)

(11) E.Lelarasmee, A.E.Ruehli \& A.L.Vincentelli : "The Waveform Relaxation Method for Time-Domain Analysis of Large Scale Integrated Circuits", IEEE Trans. on Computer Aided Design of Integrated Circuits and Systems, CAD-1, No.3 (1982)

(12) J.A.Fisher : "Trace Scheduling: A Technique for Global Microcode Compaction", IEEE Trans., C-30, No.7, pp.478-490 (1981)

(13) M.R.Garey \& D.S.Johnson : "Computers and Intractability: A Guide to the Theory of NP-Completeness", Freeman (1979)

(14) H.Kasahara \& S.Narita : "Practical Multiprocessor Scheduling Algorithms for Efficient Parallel Processing", IEEE Trans Comput., C-33, pp.1023-1029 (1984)

(15) E.G.Coffman Jr.(ed.) : "Computer and Job-shop Scheduling Theory", Wiley (1976)

(16) 笠原：「並列処理技術」, コロナ社 (1991)

(17) H.Kasahara, H.Honda \& S.Narita : "Parallel Processing of Near Fine Grain Tasks Using Scheduling on OSCAR (Optimally Scheduled Advanced Multiprocessor)", Proc. IEEE ACM. Conf. Supercomputing'90, pp856-864 (1990)

(18) 时村·前川・笠原・成田：「専用目的コンパイラ開発用 显列化中間言語とその処理系」, 情報処理学会第44回全国 大会, 6, pp.35-36 (1992)

(19) H.M.Markowitz : "The Elimination Form of Inverse and Its Application to Linear Programming", Manage. Sci., 3, pp.255269 (1957)

前川仁孝 (非会員) 炤和 42 年 11 月 27 日生。平成 $\left(\begin{array}{ll}2 & 8 \\ 2 & 1 \\ -\infty & 1\end{array}\right.$ 2 年早稲田大学理工学部電気工学科卒業。 平成 4 年同大学大学院理工学研究科電気工 学専攻修士課程修了。現在, 同大学大学院 博上課程在学中。平成 5 年日本学術振興会 特別研究員。平成 6 年早稲田大学理工学 部助手。各種アプリケーションの並列処理 に関する研究に従事。情報処理学会会員。

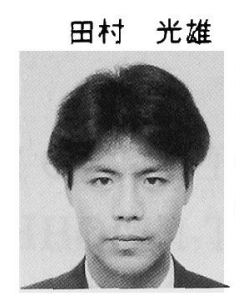

(非会買) 昭和 42 年 11 月 17 17生。平成 2 年早稻田大学理工学部電気工学科卒業。 平成 4 年同大学大学院理工学研究科電気 1 . 学夺攻修上課程修了。同年 4 月松下電器樟 業株式会社に入社。情報処理学会会貝。

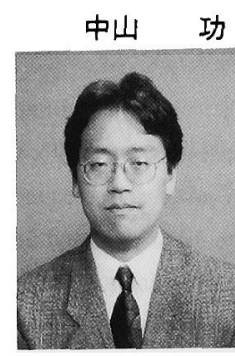

(非会員) 昭和 42 年 5 月 31 日生。平成 3 年早稲田大学理工学部電気工学科卒業。平 成 5 年同大学大学院理工学研究科電気工学 専攻修士課程修了。同年 4 月東京電力株式 会社に入社。電子情報通信学会会員。

吉成 泰彦 (非会員) 昭和 44 年 3 月 24 日生。平成 3

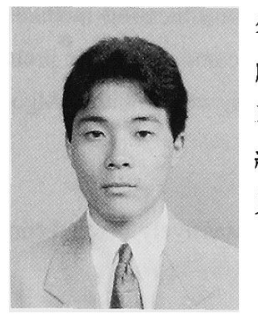
年早稲田大学理工学部電気工学科卒業。平 成 5 年同大学大学院理工学研究科電気工学 専攻修士課程修了。同年 4 月株式会社二無 総合研究所に入社。電子情報通信学会会 員。

笠原 博徳 (正員) 昭和 32 年 7 月 26 日生。昭和 55

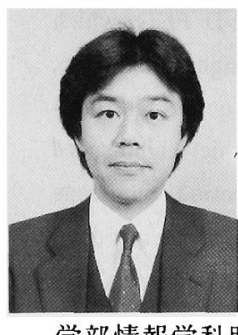
年早稲田大学理工学部電気工学科卒業。昭 和 60 年同大学大学院博士課程修了。工学 博士。昭和 58 年早稲田大学理工学部助 手。昭和 60 年学術振興会特別研究員。昭 和 61 年早稲田大学理工学部電気工学科艎 任講師。昭和 63 年早稻田大学理工学部電 気工学科助教授。平成 3 年早稲田大学理. . . 学部情報学科助教授, 現在に至る。平成元年 2 年イリノ 1 大 学: Center for Supercomputing Research \& Development 客員研究員。昭和 62 年 IFAC World Congress 第 1 回 Young Auther Prize 受賞。著書「並列処理技術」(コロナ 社)。電子情報通信学会, 情報処理学会, シミュレーショ ン学会, ロボット学会, IEEE, ACM 等の会員。 